\title{
(쇼
}

\section{High-Pressure Liquid Crystal Injection Injury of the Hand: Case Report}

\author{
Elin Yüksek Basınçlı Likit Kristal Enjeksiyon Yaralanması: Olgu Sunumu
}

\author{
Melis Efeoğlu, Serkan Emre Eroğlu, Serhad Ömercikoğlu, Haldun Akoğlu, Özge Onur, Arzu Denizbaşı
}

Department of Emergency Medicine, Marmara University Pendik Training and Research Hospital, Istanbul, Turkey

\section{ABSTRACT}

Introduction: High-pressure injection injuries of the hand have destructive effects on tissues, which can cause loss of function or amputation of the hand. With these kinds of injuries, because they present with a painless and small lesion on the affected site, it may be considerably difficult to predict the severity of the injury.

Case Report: A 58-year-old male patient was admitted to the hospital with the complaint of injection of liquid crystal with a high-pressure injection into the left hand. On physical examination, his vital signs were stable; a linear 4-mm entrance orifice was present on the thenar zone. Tetanus prophylaxis and antibiotherapy were administrated with the absence of evidence of systemic intoxication. Operation was suggested to the patient, who had expansive tissue edema and a foreign body in the magnetic resonance imaging.

Conclusion: Hand injuries are a common cause of admittance in emergency services, and we remember that the physical injury caused by the injected material may also have several systemic toxic effects. The contents of the injected material should be known and consulted at a toxic consultant center, and antidotes should be administered. It should be considered that an infection developing at the zone of the injection might worsen the prognosis by spreading. Tetanus prophylaxis and antibiotics should be administered. Severity of the injury should be determined; mild injuries should be followed up with circulation control, and moderate and severe injuries should be treated by using surgical techniques.

Keywords: High-pressure injection, hand trauma, work accident Received:07.12.2013 Accepted: 23.01.2014

\section{ÖZET}

Giriş: Elin yüksek basınçlı enjeksiyon yaralanmaları dokular üzerinde yıkıcı etkiye sahip olup, etkilenen elde ciddi fonksiyon kaybı ya da ampütasyona neden olabilir. Bu çeşit yaralanmalarda, etkilenen bölgede genellikle ağrısız ve ufak bir lezyon bulunduğundan yaralanmanın ciddiyetini tahmin etmek oldukça güç olabilir.

Olgu Sunumu: Elli sekiz yaşında erkek hasta, basınçlı hava tabancasıyla sol eline likid kristal enjekte etmesi nedeniyle acil servisimize başvurdu. Vital bulguları stabil olan hastanın muayenesinde sol el palmar yüz tenar bölgede $4 \mathrm{~mm}$ boyutunda lineer giriş deliği mevcuttu. Sistemikzehirlenme bulguları olmayan hastaya tetanoz proflaksisi ve geniş spektrumlu antibioterapi uygulandı. Çekilen el manyetik rezonans görüntülemede yaygın doku ödemi ve yabancı cisim tespit edilen hastaya ortopedi bölümü tarafından operasyon önerildi.

Sonuç: Sanayi bölgelerine yakın olan acil servislerde el yaralanmaları sıklıkla başvuru sebebi olup özellikle enjeksiyon yaralanmalarında enjekte edilen materyalin neden olduğu fiziksel hasarın yanı sıra, ciddi sistemik zehirli etkilerinin de bulunduğu unutulmamalıdır. Enjekte edilen maddenin içeriği öğrenilerekzehir danışma merkezine danışıımalı ve mevcut ise hastaya antidot verilmelidir. Enjekte edilen maddenin giriş yerinde ve yayıldığı dokularda gelişebilecek bir enfeksiyonun prognozu kötü yönde etkileyebileceği unutulmamalı ve hastalara geniş spektrumlu antibiyotikler ve tetanoz proflaksisi başlanmalıdır. Yaralanmanın ciddiyeti belirlenmeli; hafif yaralanmalar dolaşım kontrolü yapılarak, orta ve ciddi yaralanmalar ise cerrahi yöntemler kullanılarak tedavi edilmelidirler.

Anahtar Kelimeler: Yüksek basınçlı enjeksiyon, el travması, iş kazası

Geliş Tarihi: 07.12.2013 Kabul Tarihi: 23.01.2014

\section{Giriş}

Elin yüksek basınçlı enjeksiyon yaralanmaları nadir görülmekte olup doku yaralanmasının derecesi genellikle hafife alınmaktadır (1). Bu tür yaralanmalar dokular üzerinde ciddi tahrip edici etkiye sahiptir ve etkilenen elde fonksiyon kaybı ve amputasyonla 


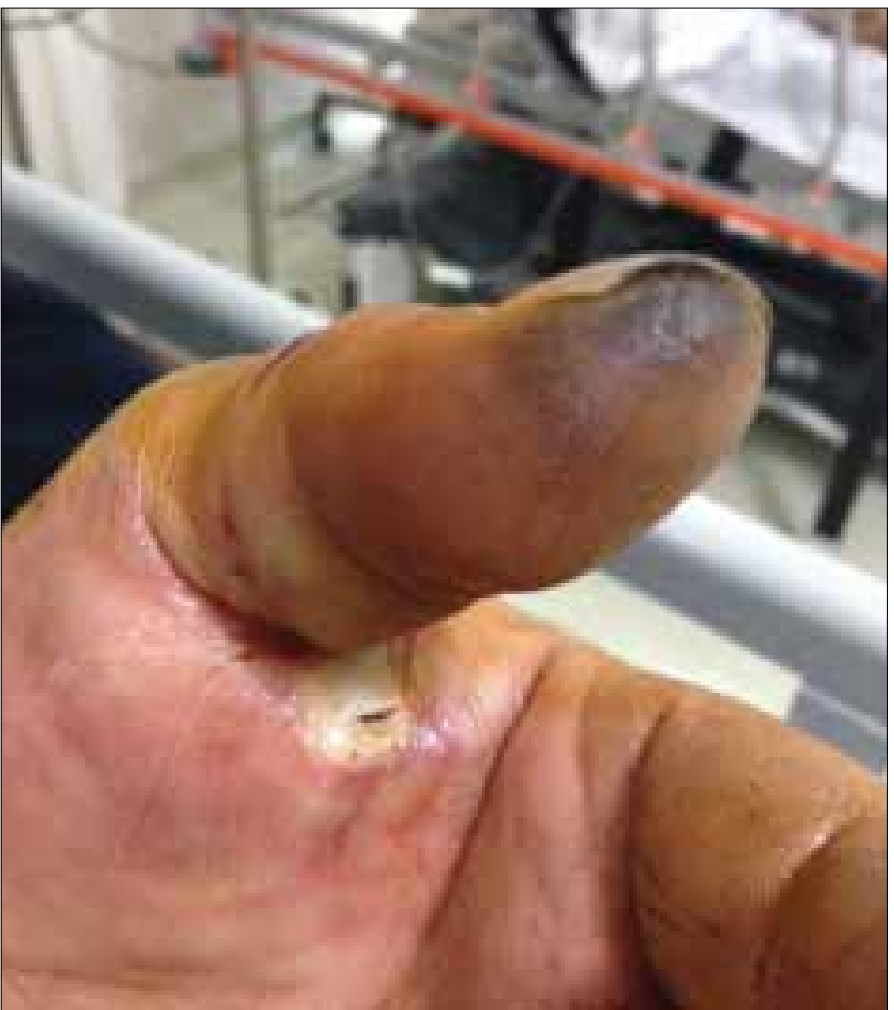

Resim 1. Yaralanma alanı, Sol el

sonuçlanan kötü prognozlu bir iyileşme süreci görülebilmektedir (2). Etkilenen elde veya parmakta sadece küçük, noktasal ve genellikle ağrısız bir lezyon bulunduğundan yaralanmanın ciddiyetini ve gelişebilecek komplikasyonları tahmin etmek oldukça güçtür (3). Yaralanmanın ciddiyeti enjekte edilen maddenin enjeksiyon basıncına, maddenin özelliklerine, hacmine ve toksisitesine bağlıdır. Erken dekompresyon, enjekte edilen maddenin cerrahi olarak temizlenmesi ve nekrozektominin prognoz üzerinde olumlu etkisi sebebiyle, bu hastalar dikkatli bir şekilde değerlendirilip hızlı bir şekilde tedavi edilmelidir (1). Bazı vakalarda tedavi, dolaşım bozukluğu bulguları sebebiyle yapılan ampütasyonlara kadar genişletilebilir (4)

Bu olgu sunumda; iş yerinde basınçlı hava tabancasıyla çalışırken, eline likit kristal enjeksiyonu gerçekleşen hastanın yönetimine yer verilmiştir

\section{Olgu Sunumu}

58 yaşındaki erkek hasta, kaza sonucu sol eline basınçlı tabanca ile likit kristal enjekte etmesi nedeniyle acil servisimize başvurdu. Daha önce bilinen bir rahatsızlığı bulunmayan hastanın başvuru anındaki genel görünümü iyi ve vital bulguları normal idi. Yapılan fizik muayenede, sol el tenar bölge 1. metakarp proksimalinde 4 mm' lik lineer giriş deliği mevcuttu (Resim 1). Periferik nabızlar açık, kapiller geri dolum zamanı 2 saniyenin altında idi. Lezyonun çevresindeki ilk 10 mm'lik alan soluk iken, daha distali ödemli ve eritemli idi. Palpasyonla ağı tarifleyen hastada, belirgin nöromotor kayıp da saptanmadı. Yaralanma yerini de içine alacak şekilde 2-5 metakarplar

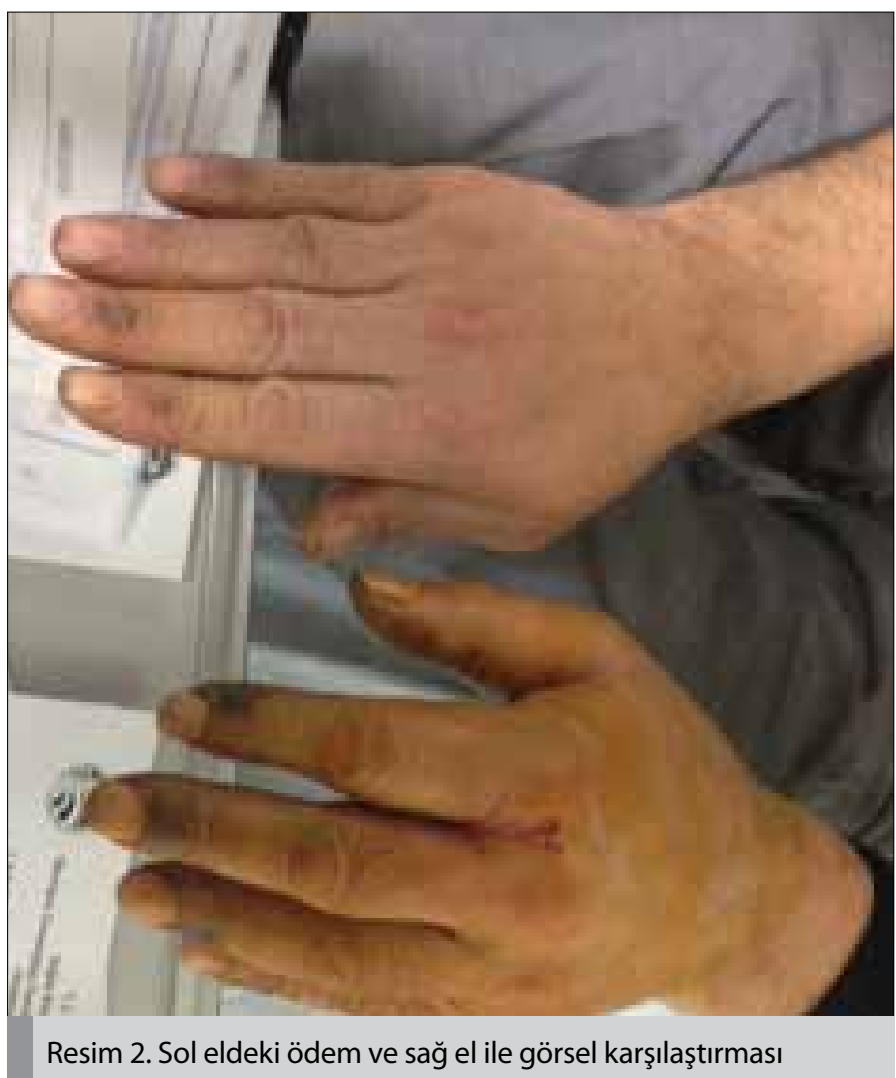

arası el çevresi 27 cm ölçülen hastanın diğer elindeki (sağ) ölçüm ise, $23 \mathrm{~cm}$ idi (Resim 2). Hastanın diğer sistemlere ait muayene bulguları ise, normaldi. Tetanoz proflaksisi yapılan, gram pozitif ve negatif mikroorganizmalara yönelik oral antibiyoterapi başlanan hastanın sol el iki yönlü direk grafisinde patolojik bulguya rastlanmadı. Çekilen sol el MR (Manyetik Rezonans) görüntülemesinde (Resim 3) çok sayıda yabancı cisim ve yoğun doku ödemi tespit edildi. Ortopedi kliniğince operasyon önerilen; ancak, dış merkezde opere olmak istediğini bildiren hasta kendi isteği ile acil servisten ayrıldı. Operasyon sonrası tarafımızca tekrar görülen hastanın, doku içine penetre olan likit kristal parçalarının (Resim 4) çıkarıldığı, komplikasyon gelişmediği ve poliklinik takiplerinin devam ettiği öğrenildi.

\section{Tartışma}

Genellikle sanayi bölgelerinde meydana gelen yüksek basınçlı enjeksiyon yaralanmaları erkeklerde daha sık görülür. Çoğunlukla, non-dominant elin maruz kaldığı $(5,6)$ yaralanma vakalarının \%50 sinden fazlasında işaret parmağı etkilenmektedir (7). Cinsiyet, maruz kalan el ve yaralanan parmak düşünüldüğünde; olgumuz, bu literatür bilgilerine uymaktadır.

Tempelman ve ark. 7 bar'dan yüksek basınçların deriyi penetre etmeye yetebileceğini, daha yüksek basınçlarda ise subkutanöz dokunun infiltre olması için cilde herhangi bir temasın olması gerekmediğini rapor etmişlerdir (2). Enjeksiyon yaralanmaları sonucunda, etkilenen bölgede genellikle noktasal bir lezyon mevcut olup hafif semptom ve muayene bulguları mevcuttur (8). Ancak, enjekte edilen maddenin kimyasal irritan etkisi akut inflamasyonu 


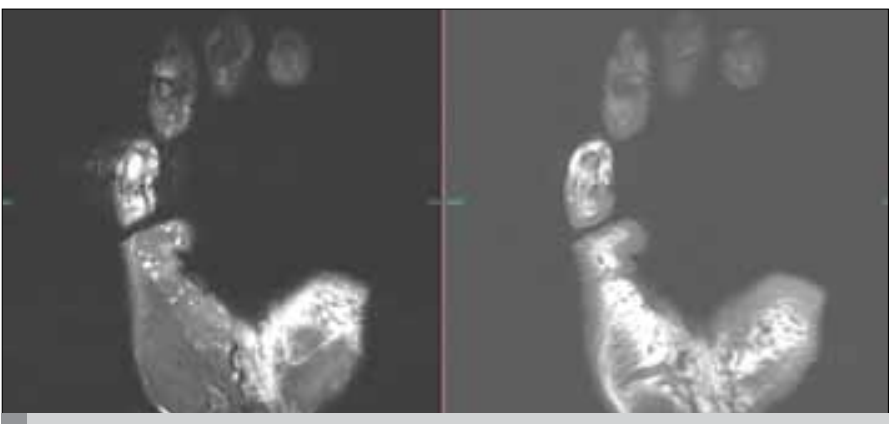

Resim 3. MRI görüntüleme, Sol el. Belirgin doku ödemi

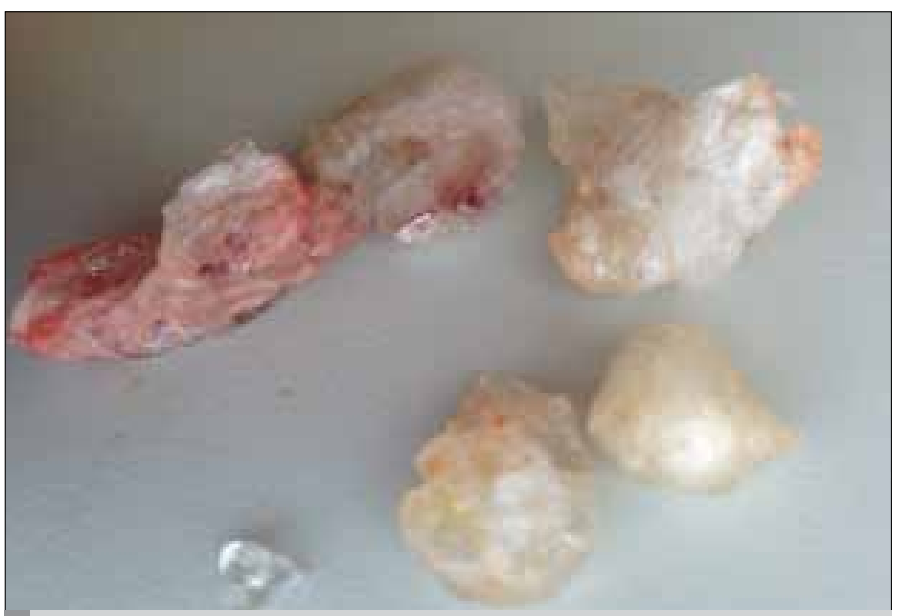

Resim 4. Operasyon ile çıkartılan katılaşmış yabancı cisim parçaları

tetikleyerek; doku ödemine, tamponada, intravasküler tromboza ve dolaşımda bozulmaya yol açabilir. Yine, iskemi ve nekrozun neden olduğu sekonder enfeksiyonlar ile tablo daha da ağırlaşabilir (9). Bu sebepten dolayl; diğer tedavilere ek olarak, hastalara gram pozitif ve gram negatif mikroorganizmalara etkili antibiyotiklerin de başlanmasında yarar vardır (5). Hastalar sistemik zehirlenme açısından dikkatli bir şekilde takip edilmeli, eğer maddenin içeriği biliniyorsa zehir danışma merkezi ile irtibata geçilmelidir. Sistemik zehirlenme bulguları varlığında hastaya destek tedavisi başlanmalı, enjekte edilen likitin kimyasal yapısı incelenmeli, eğer bilinen bir antidotu var ise en kısa sürede hastaya uygulanmalıdır.

Olgumuzda, enjekte edilen likit kristalin miktarı bilinmese de, hastanın sol elindeki yaygın ödem ve fonksiyon kaybı; yüksek miktarda likit kristalin enjekte olarak kimyasal etkilenme oluştuğunun göstergesi olabilir. Aynı bulgular, elin derin dokularına penetrasyon gerçekleştiğinin işareti olarak da düşünülebilir. Bu klinik bulgulara rağmen enfeksiyon gelişmemesinin sebebi acil serviste başlanan erken antibiyoterapi olabilir. Bu erken tedavi yaklaşımı sayesinde, hastane reddinden kaynaklanan operasyon gecikmesinin dezavantajları da ortadan kaldırılmış olabilir.

\section{Sonuç}

Iş kazası vakalarının, sanayi bölgelerine yakın konumda bulunan acil servislere daha fazla getirileceği gerçeği ile; bu konumdaki hastaneler ve bu merkezlerdeki sağlık ekipleri sanayi bölgesinin niteliğine göre hazırlıklı olmalıdır. Olgumuzda olduğu gibi görünür travma izlerine sahip olgularda, ikincil travma komplikasyonları akıldan çıkarımamalıdır. Uygun tedavi yöntemini bilen ve acil karar verebilme yetisine sahip personeller sayesinde komplikasyon oranları da azalacaktır

Informed consent: Written informed consent was obtained from patients who participated in this case.

Peer review: Externally peer-reviewed.

Author contributions:Concept-M.E.,S.E.E.;Design-M.E,S.Ö.;Supervision - S.E.E, H.A.; Materials - S.Ö., H.A.; Data Collection and/or Processing - Ö.O., M.E.; Analysis and/or Interpretation - S.E.E., A.D., M.E.; Literature Review A.D., Ö.O.; Writer - M.E., S.E.E.; Critical Review - A.D., H.A., S.E.E.

Conflict of interest: No conflict of interest was declared by the authors.

Financial Disclosure: The authors declared that this study has received no financial support.

Hasta Onamı: Hasta onamı bu çalışmaya katılan hastadan alınmıştır.

Hakem değerlendirmesi: Dış bağımsız.

Yazar Katkıları: Fikir - M.E., S.E.E.;Tasarım - M.E, S.Ö.; Denetleme - S.E.E, H.A.; Malzemeler - S.Ö., H.A.; Veri toplanması ve/veya işlemesi - Ö.O. M.E.; Analiz ve/veya yorum - S.E.E., A.D., M.E.; Literatür taraması - A.D., Ö.O.; Yazıyı yazan - M.E., S.E.E.; Eleştirel İnceleme - A.D., H.A., S.E.E.

Çıkar Çatışması: Yazarlar çıkar çatışması bildirmemişlerdir.

Finansal Destek: Yazarlar bu çalışma için finansal destek almadıklarını beyan etmişlerdir.

\section{Kaynaklar}

1. Rappold G, Rosenmayr E. High-pressure injection injuries of the hand. Pathogenesis, problems and therapy. Handchir Mikrochir Plast Chir 2001; 33: 332-41. [CrossRef]

2. Tempelman T, Borg D, Kon M. Verwonding van de hand door een hogedrukspuit: vaak grote onderhuidse schade. Ned Tijdschr Geneeskd 2004; 148: 2334-38.

3. Verhoeven N, Hierner R. High-pressure injection injury of the hand: an often underestimated trauma: case report with study of the literature. Strategies Trauma Limb Reconstr. 2008; 3: 27-33. [CrossRef]

4. Lewis H, Clarke P, Kneafsey B, Brennen MA. 10-year review of high-pressure injection injuries to the hand. J Hand Surg 1998; 23: 479-81. [CrossRef]

5. Sirio CA, Smith JS Jr, Graham WP. High-pressure injection injuries of the hand. A review. Am Surg 1989; 55: 714-8.

6. Stoffelen D., De Smet L., Broos P. Delayed diagnosis of high-pressure injection injuries to the finger. A case report and review of the literature. Acta Orhop Belg 1994; 60: 332-3.

7. Wieder A, Lapid O, Plakht Y, Sagi A. A Long term follow-up of high-pressure injection injuries to the hand. Plast Reconstr Surg 2006; 117: 186-9. [CrossRef]

8. Hart RG, Smith GD, Haq A. Prevention of high-pressure injection injuries to the hand. Am J Emerg Med. 2006; 24: 73-6. [CrossRef]

9. Valentino M, Rapisarda V, Fenga C. Hand injuries due to high-pressure injection devices for painting in shipyards: circumstances, management and outcome in twelve patients. Am J Ind Med 2003; 43: 539-42. [CrossRef] 